\title{
Indole-3-Acetic Acid/Horseradish Peroxidase-Induced Apoptosis Involves Cell Surface CD95 (Fas/APO-1) Expression
}

\author{
Dong-Seok Kim, ${ }^{a, b}$ So-Young Kim, ${ }^{b}$ Yun-Mi Jeong,${ }^{b}$ Sang-Eun Jeon, ${ }^{b}$ Myo-Kyoung Kim, ${ }^{c}$ \\ Sun-Bang Kwon, ${ }^{d}$ and Kyoung-Chan PARK ${ }^{*, b}$ \\ ${ }^{a}$ Research Division for Human Life Sciences, Seoul National University; ${ }^{b}$ Department of Dermatology, Seoul National \\ University College of Medicine; 28 Yongon-Dong, Chongno-Gu, Seoul 110-744, Korea: ${ }^{c}$ Pharmacy Practice, Thomas J. \\ Long School of Pharmacy, University of the Pacific; Stockton, CA, U.S.A.: and ${ }^{d}$ Welskin Co., Ltd.; 28 Yongon-Dong, \\ Chongno-Gu, Seoul 110-744, Korea. Received February 15, 2006; accepted May 23, 2006
}

\begin{abstract}
Recently, we showed that a combination of indole-3-acetic acid (IAA) and horseradish peroxidase (HRP) produces hydrogen peroxide $\left(\mathrm{H}_{2} \mathrm{O}_{2}\right)$, and that this leads to the apoptosis of $\mathrm{G361}$ human melanoma cells. In the present study, flow cytometric analysis confirmed that $\mathrm{H}_{2} \mathrm{O}_{2}$ is involved the IAA/HRP-induced apoptotic process. We also found that IAA/HRP increases cell surface CD95 (Fas/APO-1) expression, and that this is blocked by catalase treatment. Furthermore, blocking CD95 with a neutralizing antibody significantly restored IAA/HRPinduced apoptosis. In addition, the IAA/HRP-induced activations of CD95 downstream molecules, i.e., caspase-8, Bid, and caspase-3, were also inhibited by catalase. Moreover, a caspase-8 inhibitor significantly blocked IAA/HRP-induced apoptosis. These results indicate that IAA/HRP-induced apoptosis involves a CD95-initiated death receptor signaling pathway initiated by hydrogen peroxide.
\end{abstract}

Key words indole-3-acetic acid; horseradish peroxidase; CD95 (Fas/APO-1); apoptosis; melanoma

Indole-3-acetic acid (IAA), otherwise known as the plant growth hormone auxin, is biologically active in yeast and animal cells, ${ }^{1)}$ and it has been suggested that the IAA and horseradish peroxidase (HRP) combination is a possible novel anticancer treatment. ${ }^{2,3)}$ Moreover, it is well known that IAA alone has no cytotoxic effect and that it becomes active after oxidative decarboxylation by HRP. ${ }^{4)}$ Recently, we demonstrated that the IAA/HRP combination induces the apoptosis of G361 human melanoma cells, ${ }^{5)}$ and we suggested that hydrogen peroxide $\left(\mathrm{H}_{2} \mathrm{O}_{2}\right)$ is a major mediator of IAA/HRP-induced apoptosis. ${ }^{6}$ )

$\mathrm{H}_{2} \mathrm{O}_{2}$ is known to regulate intracellular signal transduction pathways and to induce apoptosis in a variety of cell types. ${ }^{7}{ }^{8)}$ Moreover, mitogen-activated protein (MAP) kinase family members, like extracellular signal-regulated kinase (ERK) and p38 MAP kinase, are activated by extracellular stimuli like ultraviolet radiation (UV) and free radicals including $\mathrm{H}_{2} \mathrm{O}_{2}{ }^{9}{ }^{, 10}$ ) In addition, it has been shown that MAP kinase activation is involved in $\mathrm{H}_{2} \mathrm{O}_{2}$-induced apoptosis. ${ }^{711)}$

CD95 (Fas/APO-1) is a member of the tumor necrosis factor (TNF) receptor superfamily, which regulate death receptor-mediated apoptosis, ${ }^{12)}$ and furthermore, it has been reported that CD95 activation by agonistic antibodies or CD95 ligand induces apoptosis. ${ }^{13)}$ Moreover, UV also induces apoptosis via direct CD95 activation. ${ }^{14)}$ Caspases are a family of cysteine-dependent aspartate-specific proteases, and play a major role in apoptosis, ${ }^{15}$ ) and when CD95 is triggered by various stimuli, caspase- 8 is cleaved and activated, ${ }^{16)}$ and as an initiator of apoptosis, activated caspase- 8 then cleaves and activates executive caspases, like caspase-3. In addition, caspase- 8 can cleave Bid, the proapoptotic member of the Bcl-2 family, and after cleavage, Bid translocates to mitochondria and triggers cytochrome $\mathrm{C}$ release. ${ }^{17)}$

$\mathrm{H}_{2} \mathrm{O}_{2}$ is known to increase the expression of death receptor CD95 and to induce apoptosis via a death receptor-mediated pathway. ${ }^{18)}$ Catalase is a major scavenger of $\mathrm{H}_{2} \mathrm{O}_{2}$, and we hypothesized that CD95 may be influenced by IAA/HRP if
$\mathrm{H}_{2} \mathrm{O}_{2}$ is involved in IAA/HRP-induced apoptosis, and thus, we examined the effects of catalase against the IAA/HRP-induced death pathway including CD95 expression. In the present study, NADPH was used to protect catalase from inactivation, and hence to increase its efficiency. ${ }^{19)}$

We hypothesized that $\mathrm{H}_{2} \mathrm{O}_{2}$ is a major mediator of IAA/HRP-induced apoptosis. However, $\mathrm{H}_{2} \mathrm{O}_{2}$ itself has many problems in terms of its clinical use. For example, $\mathrm{H}_{2} \mathrm{O}_{2}$ can also injure normal tissues, when it is applied directly. In contrast, because IAA alone is not cytotoxic, IAA could be safely administered to patients. Therefore, circulating IAA could be activated exclusively in tumors, if HRP could be targeted to cancer cells. Thus, because the mechanisms of IAA/HRP-mediated apoptosis remained substantially unknown, we examined the CD95-related apoptotic pathways.

In the present study, we investigated whether CD95 activation is related to IAA/HRP-induced apoptosis in G361 human melanoma cells. Our results show that catalase blocks IAA/HRP-induced cell surface CD95 expression and IAA/HRP-mediated signal transduction pathways. These results suggest that IAA/HRP-induced $\mathrm{H}_{2} \mathrm{O}_{2}$ activates the CD95-mediated apoptotic pathway.

\section{MATERIALS AND METHODS}

Materials Indole-3-acetic acid, horseradish peroxidase, catalase, NADPH, and $\mathrm{H}_{2} \mathrm{O}_{2}$ were obtained from Sigma (St. Louis, MO, U.S.A.); antibodies recognizing caspase-8 (sc7890), caspase-9 (sc-8355), and actin (I-19) from Santa Cruz Biotechnology, Inc. (Santa Cruz, CA, U.S.A.); antibodies for phospho-specific ERK1/2 (Thr202/Tyr204, \#9101S), phospho-specific p38 MAPK (Thr180/Tyr182, \#9211S), and cleaved caspase-3 (\#9661) from Cell Signaling Technology, Inc. (Beverly, MA, U.S.A.). Anti-Bid antibody (AF860) was obtained from R\&D systems (Minneapolis, MN, U.S.A.), and anti-CD95 neutralizing antibody (ZB4, \#05-338) from Upstate Biotechnology, Inc. (Lake Placid, NY, U.S.A.). The cas- 
pase- 8 inhibitor z-IETD-FMK was from Merck (Darmstadt, Germany).

Cell Cultures The lightly pigmented human melanoma cell line, G361 (ATCC, Rockville, MD, U.S.A.), was grown in RPMI supplemented with $10 \% \mathrm{FBS}$ and $1 \%$ penicillinstreptomycin $(10000 \mathrm{U} / \mathrm{ml}$ and $10000 \mu \mathrm{g} / \mathrm{ml}$, respectively) in $5 \% \mathrm{CO}_{2}$ at $37^{\circ} \mathrm{C}$.

Crystal Violet Assay G361 cells $\left(4 \times 10^{4}\right.$ cells/well $)$ were seeded into 24 -well plates, and after serum starvation for $24 \mathrm{~h}$ were incubated with IAA/HRP in the presence or absence of a neutralizing anti-CD95 antibody $(1 \mu \mathrm{g} / \mathrm{ml})$ for $6 \mathrm{~h}$ at $37^{\circ} \mathrm{C}$ in $5 \% \mathrm{CO}_{2}$. Cell viabilities were determined using crystal violet assays. ${ }^{20)}$ Briefly, culture medium was removed and replaced with $0.1 \%$ crystal violet in $10 \%$ ethanol for $5 \mathrm{~min}$ at room temperature. The cells were then rinsed four times in distilled water, and adherent crystal violet was extracted with $95 \%$ ethanol. Absorbances were determined at $590 \mathrm{~nm}$ using an ELISA reader (TECAN, Salzburg, Austria).

Western Blot Analysis After serum starvation for $24 \mathrm{~h}$, G361 cells were treated with IAA/HRP for the indicated times, and lysed in cell lysis buffer $[62.5 \mathrm{~mm}$ Tris- $\mathrm{HCl}(\mathrm{pH}$ $6.8), 2 \% \mathrm{SDS}, 5 \% \beta$-mercaptoethanol, $2 \mathrm{~mm}$ phenylmethylsulfonyl fluoride, protease inhibitors (Roche, Mannheim, Germany), $1 \mathrm{~mm} \mathrm{Na}_{3} \mathrm{VO}_{4}, 50 \mathrm{~mm} \mathrm{NaF}$, and $10 \mathrm{~mm}$ EDTA]. Protein aliquots of $10 \mu \mathrm{g}$ per lane were separated by SDSpolyacrylamide gel electrophoresis and blotted onto PVDFmembranes, which were then saturated with $5 \%$ dried milk in Tris-buffered saline containing $0.4 \%$ Tween 20 . Blots were incubated with the appropriate primary antibodies at a dilution of $1: 1000$, and then further incubated with horseradish peroxidase-conjugated secondary antibody. Bound antibodies were detected using enhanced chemiluminescence plus kits (Amersham International, Little Chalfont, U.K.).

Flow Cytometric Analysis for Apoptosis After treating G361 cells with IAA/HRP for 6 h, culture supernatants were collected for floating dying and apoptotic cells. Adherent cells were then harvested by brief trypsinization. Cell fractions were then combined and washed with PBS. Cells were labeled with FITC-conjugated annexin $\mathrm{V}$ and propidium iodide (PI) using TACS ${ }^{\mathrm{TM}}$ Annexin V-FITC kits (Trevigen, Gaithersburg, MD, U.S.A.), and flow cytometric analyses were performed on a FACSCalibur ${ }^{\mathrm{TM}}$ (Becton Dickinson, San Jose, CA, U.S.A.). The fluorescences of FITC-labeled and PI-labeled cells were then measured.

Flow Cytometric Analysis for CD95 Cell Surface Expression Cells collected as described in "Flow Cytometric Analysis for Apoptosis" above were also incubated with antiCD95 antibody (\#PC69) (Calbiochem, San Diego, CA, U.S.A.) for $1 \mathrm{~h}$ at $4{ }^{\circ} \mathrm{C}$, washed in PBS, and incubated with FITC-conjugated goat anti-rabbit secondary antibody (Santa Cruz Biotechnology, Inc., Santa Cruz, CA, U.S.A.) for $1 \mathrm{~h}$ at $4{ }^{\circ} \mathrm{C}$. After washing in PBS, flow cytometric analyses were performed on a FACSCalibur ${ }^{\mathrm{TM}}$. The fluorescences of FITClabeled cells were then measured.

Confocal Microscopy After serum starvation for $24 \mathrm{~h}$, dishes containing G361 cells were stimulated with IAA/HRP, $\mathrm{UVB}$, or $\mathrm{H}_{2} \mathrm{O}_{2}$. After $1 \mathrm{~h}$, cells were fixed for $10 \mathrm{~min}$ in $10 \%$ formaldehyde, incubated for $10 \mathrm{~min}$ in $\mathrm{NH}_{4} \mathrm{Cl}$, and then for $10 \mathrm{~min}$ in $0.1 \%$ Triton $\mathrm{X}-100$. The cells were then incubated overnight at $4{ }^{\circ} \mathrm{C}$ with an antibody directed against CD95 (Calbiochem, San Diego, CA, U.S.A.) at $1: 100$ in PBS.
After 3 washes in PBS, cells were further incubated with FITC-labeled secondary antibody (Santa Cruz Biotechnology, Santa Cruz, CA, U.S.A.) at $1: 100$ in PBS for $1 \mathrm{~h}$ at room temperature. Specimens were analyzed by confocal microscopy (LSM510, Carl Zeiss AG, Germany).

Statistics Differences were assessed for significance using the Student's $t$-test.

\section{RESULTS}

IAA/HRP Induced Apoptosis, and This Was Prevented by Catalase The translocation of phosphatidylserine is an early event in the apoptotic process, and annexin $\mathrm{V}$ can bind to phosphatidylserine on the surfaces of cells undergoing apoptosis. To determine whether IAA/HRP-induced apoptosis involves $\mathrm{H}_{2} \mathrm{O}_{2}$, flow cytometry was used to differentiate apoptotic and viable cells in the presence or absence of catalase. The figures in Fig. 1 show various cellular states according to annexin $\mathrm{V}$ binding and propidium iodide (PI) uptake. Cells were categorized into four populations after $6 \mathrm{~h}$ of IAA/HRP treatment; vital cells (annexin $\mathrm{V}^{-} / \mathrm{PI}^{-}$), early apoptotic cells (annexin $\mathrm{V}^{+} / \mathrm{PI}^{-}$), late apoptotic cells (annexin $\mathrm{V}^{+} / \mathrm{PI}^{+}$), and necrotic cells (annexin $\mathrm{V}^{-} / \mathrm{PI}^{+}$). Our results show that IAA $(500 \mu \mathrm{M}) / \mathrm{HRP}(1.2 \mu \mathrm{g} / \mathrm{ml})$ treatment induced significant apoptosis, and that this caused more than $70 \%$ of cells to be in a state of early or late apoptosis after $6 \mathrm{~h}$ treatment (Fig. 1B). However, catalase $(1000 \mathrm{U} / \mathrm{ml})$, a specific $\mathrm{H}_{2} \mathrm{O}_{2}$ scavenger prevented IAA/HRP-induced apoptosis and kept the cells in a vital state (annexin $\mathrm{V}^{-} / \mathrm{PI}^{-}$) (Fig. $1 C)$. In addition, it was recently reported that NADPH protects catalase from oxidative damage. ${ }^{19)}$ Thus, we further investigated whether NADPH shows an additive effect with catalase, and found that the addition of NADPH $(50 \mu \mathrm{M})$ with catalase $(1000 \mathrm{U} / \mathrm{ml})$ almost completely blocked IAA/HRPinduced apoptosis (Fig. 1D).

IAA/HRP Induced MAP Kinase Activation We previously reported that $\mathrm{H}_{2} \mathrm{O}_{2}$ plays an important role in the IAA/HRP-induced activations of MAP kinases. ${ }^{6)}$ Here, we found that IAA/HRP activated ERK and p38 MAP kinases like $\mathrm{H}_{2} \mathrm{O}_{2}$, thus confirming that $\mathrm{H}_{2} \mathrm{O}_{2}$ is an important mediator of IAA/HRP reactions (Fig. 2). Moreover, IAA (500

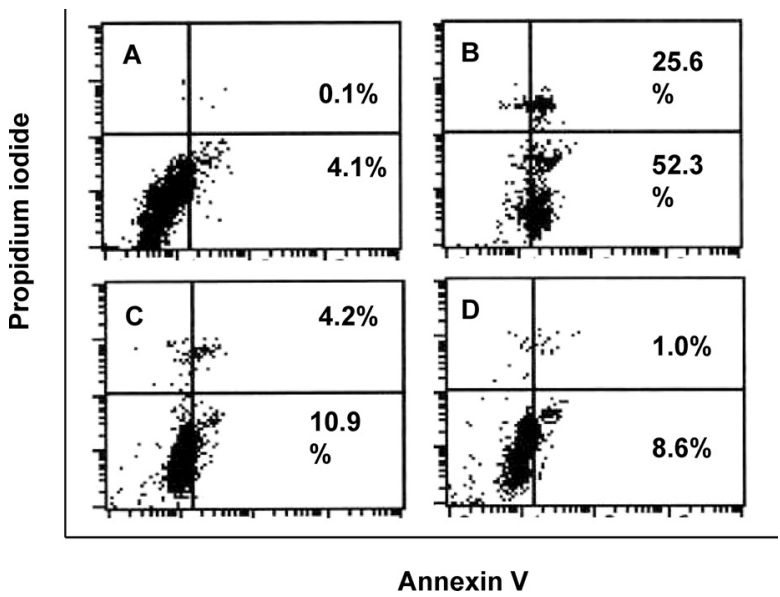

Fig. 1. IAA/HRP-Induced Apoptosis Is Blocked by Catalase

After serum starvation, G361 cells were treated with IAA $(500 \mu \mathrm{M})$ and HRP $(1.2 \mu \mathrm{g} / \mathrm{ml})$ with/without catalase $(1000 \mathrm{U} / \mathrm{ml})$ and $/$ or NADPH $(50 \mu \mathrm{M})$. After $6 \mathrm{~h}$, apoptotic cells were counted using a flowcytometer, as described in Materials and Methods; A: control, B: IAA/HRP, C: IAA/HRP+catalase, D: IAA/HRP+catalase/NADPH. 


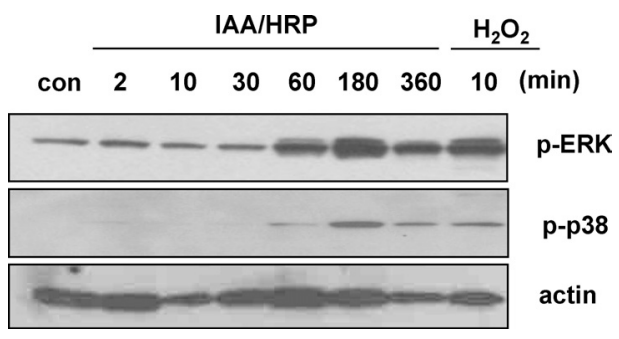

Fig. 2. Effects of IAA/HRP on the Activations of ERK and p38

After serum starvation, G361 cells were stimulated with IAA $(500 \mu \mathrm{M})$ and HRP $(1.2 \mu \mathrm{g} / \mathrm{ml})$ for the indicated times; $\mathrm{H}_{2} \mathrm{O}_{2}(2 \mathrm{mM})$ was used as a positive control. Cell lysates were then subjected to Western blot analysis with antibodies against phosphospecific ERK or p38 MAP kinase. Equal protein loadings were confirmed using antiactin antibody.
Control

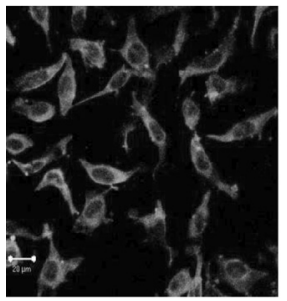

IAA+HRP

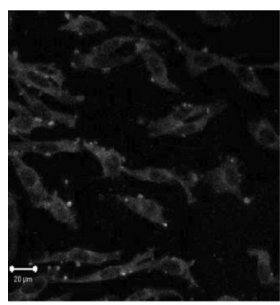

UVB
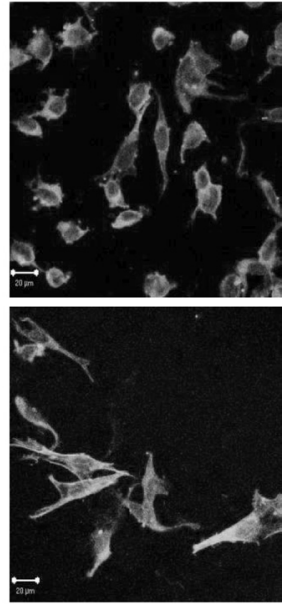

$\mathrm{H}_{2} \mathrm{O}_{2}$
Fig. 3. IAA/HRP Induced CD95 Aggregation on Cell Surfaces

After serum starvation, G361 cells were treated with IAA $(500 \mu \mathrm{M}) / \mathrm{HRP}(1.2 \mu \mathrm{g} / \mathrm{ml})$, UVB $\left(200 \mathrm{~mJ} / \mathrm{cm}^{2}\right)$, or $\mathrm{H}_{2} \mathrm{O}_{2}(2 \mathrm{mM})$, and $1 \mathrm{~h}$ later cells were incubated with anti-CD95 antibody and stained with FITC-conjugated secondary antibody against CD95, as described in Materials and Methods. Fluorescence was detected by confocal microscopy. Bars, $20 \mu \mathrm{m}$.

$\mu \mathrm{M}) / \mathrm{HRP}(1.2 \mu \mathrm{g} / \mathrm{ml})$ induced the delayed activations of ERK and p38 MAP kinases, which began after $1 \mathrm{~h}$ of IAA/HRP treatment. In addition, phosphorylated ERK and p38 levels were maintained for at least $6 \mathrm{~h}$.

IAA/HRP Induced CD95 Aggregation in G361 Cells It has been reported that ROS contributes to UVB-induced apoptosis via CD95 aggregation. ${ }^{21,22)}$ Thus, we hypothesized that IAA/HRP might also induce CD95 aggregation if $\mathrm{H}_{2} \mathrm{O}_{2}$ is involved in IAA/HRP-induced apoptosis. To investigate this possibility, three dishes of G361 cells were exposed to either IAA/HRP, UVB $\left(200 \mathrm{~mJ} / \mathrm{cm}^{2}\right)$ or $\mathrm{H}_{2} \mathrm{O}_{2}(2 \mathrm{mM})$, and cells were then stained with a FITC-conjugated secondary antibody against CD95. Subsequent confocal microscopy showed that IAA/HRP treatment caused CD95 aggregation (Fig. 3). Moreover, the same findings were observed for UVB and $\mathrm{H}_{2} \mathrm{O}_{2}$ treatments. These results strongly support our hypothesis that IAA/HRP induces CD95 aggregation, like UVB or $\mathrm{H}_{2} \mathrm{O}_{2}$.

Anti-CD95 Antibody Prevented IAA/HRP-Induced Apoptosis We next investigated whether IAA/HRP can activate $\mathrm{CD} 95$ by producing $\mathrm{H}_{2} \mathrm{O}_{2}$. Thus, $\mathrm{G} 361$ cells were ex-
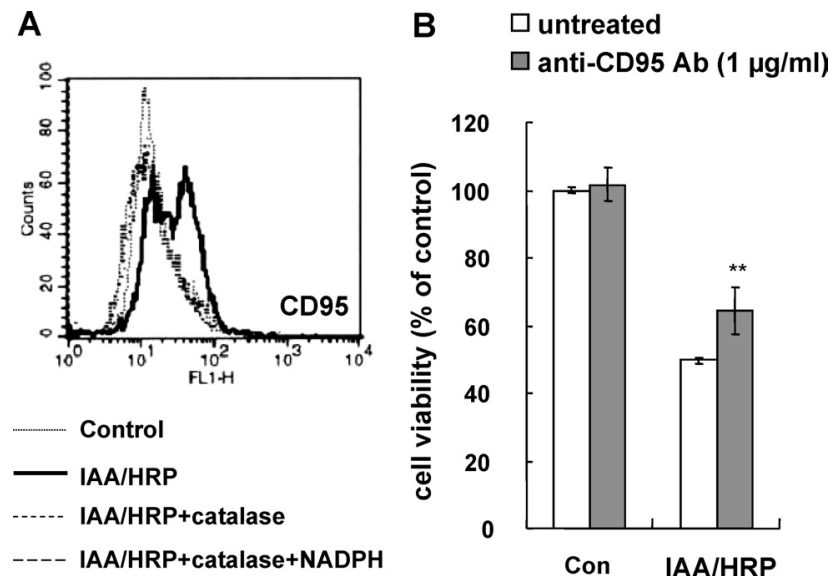

Fig. 4. IAA/HRP-Induced CD95 Expression was Blocked by Catalase

(A) After serum starvation, cells were treated with IAA $(500 \mu \mathrm{M})$ and HRP $(1.2 \mu \mathrm{g} / \mathrm{ml})$ with/without $1000 \mathrm{U} / \mathrm{ml}$ catalase and/or $50 \mu \mathrm{M}$ NADPH for $6 \mathrm{~h}$. Cells were then incubated with anti-CD95 antibody and then with FITC-conjugated secondary antibody against CD95, and finally subjected to flowcytometric analyses as described in Materials and Methods. (B) Cells were treated with IAA $(500 \mu \mathrm{M})$ and HRP $(1.2 \mu \mathrm{g} / \mathrm{ml})$ with/without a neutralizing anti-CD95 antibody $(1 \mu \mathrm{g} / \mathrm{ml})$ for $6 \mathrm{~h}$ and apoptosis was followed using crystal violet assays. Data represent means \pm S.D. of triplicate assays expressed as percentages of the untreated control. $* * p<0.01$ compared to the control. Each experiment was repeated at least twice, and representative results are shown.

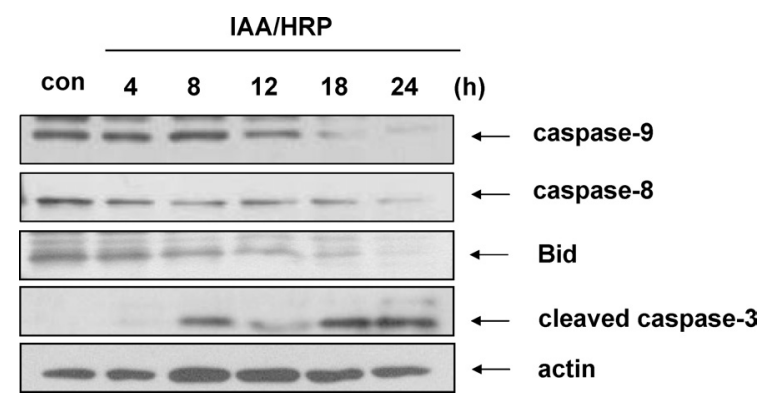

Fig. 5. IAA/HRP Activated Apoptotic Pathways

After serum starvation, G361 cells were treated with IAA $(500 \mu \mathrm{M})$ and HRP $(1.2 \mu \mathrm{g} / \mathrm{ml})$. Samples were then collected at the indicated times. Cell lysates were subjected to Western blot analysis with antibodies against procaspase-9, procaspase-8, Bid or cleaved caspase-3. Equal protein loadings were confirmed using anti-actin antibody.

posed to IAA/HRP for $6 \mathrm{~h}$ in the presence or absence of catalase. The cells were then stained with an FITC-conjugated secondary antibody against CD95. Subsequent flow cytometric analysis showed that IAA/HRP increased CD95 cell surface expression, and that this was blocked by catalase (Fig. 4A). These results indicate that $\mathrm{H}_{2} \mathrm{O}_{2}$ is a mediator of the responses induced by IAA/HRP.

To determine whether IAA/HRP-induced apoptosis is related to a CD95-mediated apoptotic pathway, G361 cells were pretreated with a neutralizing antibody directed against CD95 before being treated with IAA/HRP for $1 \mathrm{~h}$. As shown in Fig. 4B, IAA/HRP-induced apoptosis was partially prevented by pretreatment with neutralizing antibody. The above results suggest that the CD95 pathway is involved in IAA/HRP-induced apoptosis.

IAA/HRP Induced Apoptotic Pathway Activation We further investigated the nature of the operative apoptotic pathway induced by IAA $(500 \mu \mathrm{m}) / \mathrm{HRP}(1.2 \mu \mathrm{g} / \mathrm{ml})$ by using a time-course experiment. Caspases become active when they are cleaved into processed fragments, and in this experiment we used antibodies directed against the precursor forms of caspase-9, caspase-8, and Bid. As shown in Fig. 5, 


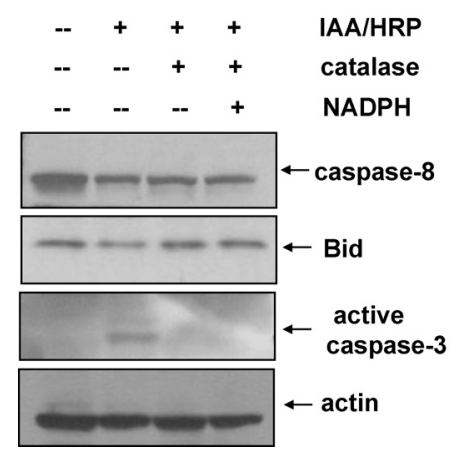

B

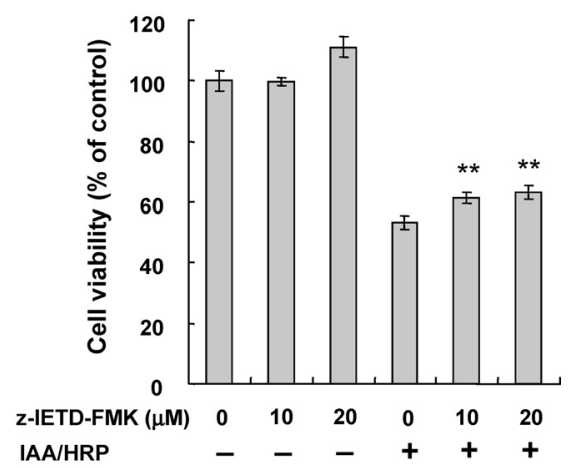

Fig. 6. The IAA/HRP-Activated Apoptotic Pathway was Blocked by Catalase

(A) After serum starvation, G361 cells were treated for $6 \mathrm{~h}$ with IAA $(500 \mu \mathrm{M})$ and HRP $(1.2 \mu \mathrm{g} / \mathrm{ml})$ with/without catalase (1000 U/ml) and/or NADPH (50 $\mu \mathrm{M})$. Cell lysates were then subjected to Western blot analysis with the indicated antibodies. Equal protein loadings were confirmed using actin antibody. (B) Cells were treated with IAA (500 $\mu \mathrm{M})$ and $\operatorname{HRP}(1.2 \mu \mathrm{g} / \mathrm{ml})$ with/without a caspase- 8 inhibitor, z-IETD-FMK for $6 \mathrm{~h}$ and apoptosis was followed using crystal violet assays. Data represent means \pm S.D. of triplicate assays expressed as percentages of the untreated control. ** $p<0.01$ compared to the IAA/HRP-treated control. Each experiment was repeated at least twice, and representative results are shown.

IAA/HRP cleaved and activated caspase-9, caspase-8, and Bid in a time-dependent manner. An antibody directed against the cleaved form of caspase- 3 was also used, and the active form of caspase- 3 was found to increase time-dependently with IAA/HRP treatment.

Catalase Inhibited a Death Receptor-Mediated Apoptotic Pathway Activated by IAA/HRP Figure 5 shows that IAA/HRP induced the activation of a death receptor-mediated apoptotic signaling pathway. After IAA/HRP treatment, the precursor forms of caspase- 8 and Bid were downregulated and the active form of caspase- 3 was up-regulated (Fig. 6A). As was expected, catalase inhibited IAA/HRP-induced caspase-8, Bid, and caspase-3 cleavages (Fig. 6A). These results indicate that a death receptor mediated apoptotic pathway is activated by the $\mathrm{H}_{2} \mathrm{O}_{2}$ produced by IAA/HRP. Thus, in order to study the effects of a caspase- 8 inhibitor, G361 cells were pretreated with z-IETD-FMK $1 \mathrm{~h}$ before treatment with IAA/HRP. As shown in Fig. 6B, IAA/HRP-induced apoptosis was partially prevented by zIETD-FMK pretreatment, which suggests that caspase- 8 is involved in IAA/HRP-induced apoptosis.

\section{DISCUSSION}

Interest in the possibility of using IAA/HRP as new cancer therapy is increasing. ${ }^{24)}$ Recently, we reported that IAA/HRP induces the apoptosis of G361 human melanoma cells, ${ }^{5)}$ and suggested that $\mathrm{H}_{2} \mathrm{O}_{2}$ is a major mediator of this IAA/HRP-induced apoptosis. ${ }^{6)}$ However, the mechanisms of IAA/HRPmediated apoptosis remained substantially unknown.

In the present study, catalase was found to reduce IAA/HRP-induced apoptosis, thus confirming that $\mathrm{H}_{2} \mathrm{O}_{2}$ is a potential mediator of IAA/HRP. On the other hand, MAP kinases are known to be important signal transduction mediators in the apoptotic process. ${ }^{9,23,24)}$ In addition, it has been reported that the activations of ERK and p38 MAP kinase play key roles in $\mathrm{H}_{2} \mathrm{O}_{2}$-induced apoptosis. ${ }^{7,25)}$ Here, we demonstrated that IAA/HRP induces the activations of ERK and p38 (as does $\mathrm{H}_{2} \mathrm{O}_{2}$ ), and thus our findings support a mediatory role for $\mathrm{H}_{2} \mathrm{O}_{2}$ in IAA/HRP induced apoptosis.

CD95 activation triggers the death receptor-mediated apoptotic cell death process, and it has been reported that $\mathrm{H}_{2} \mathrm{O}_{2}$ increases CD95 expression and induces the apoptosis of murine intestinal epithelial cells and neuronal PC12 cells. ${ }^{18,26)}$ Moreover, UV-generated ROS was found to lead to CD95 activation, and thus to apoptotic cell death. ${ }^{22)}$ The caspase- 8 pathway plays a key role in CD95-mediated apoptotic cell death, and to understand the role of IAA/HRP in CD95mediated apoptosis, we investigated CD95 expression and the nature of the CD95-mediated apoptotic pathway after IAA/HRP treatment. We examined total CD95 expression after IAA/HRP treatment, but by Western blotting this expression was not significantly increased by IAA/HRP (data not shown). It has been reported that p53 activation may increase surface CD95 expression by promoting Fas transport from the Golgi complex, ${ }^{27)}$ and in a recent report, we showed that IAA/HRP leads to p53 activation. ${ }^{6)}$ Moreover, in the present study, we found that IAA/HRP increased surface CD95 expression, and that this was blocked by catalase. These results indicate that IAA/HRP-induced apoptosis may be due to increased CD95 export to the cell surface, and that this may be mediated by $\mathrm{H}_{2} \mathrm{O}_{2}$. In further experiments, we found that an antagonizing anti-CD95 antibody restored IAA/HRP-induced apoptosis, thus suggesting that increased CD95 surface expression is involved in IAA/HRP-mediated response. However, since IAA/HRP-mediated apoptosis was found to be blocked only partially by antagonizing antiCD95 antibody (Fig. 4B), the involvements of other apoptotic pathways should also be considered.

Furthermore, IAA/HRP activated CD95 downstream molecules, such as, caspase- 8 and Bid, which are known to trigger mitochondrial pathway activation. ${ }^{28)}$ Our results show that caspase- 8 activation started to occur after $4 \mathrm{~h}$ of IAA/HRP treatment (Fig. 5), and Bid cleavage was observed to increase in parallel with caspase- 8 activation, whereas caspase- 9 activation occurred after $12 \mathrm{~h}$ of IAA/HRP treatment. The mitochondrial apoptotic pathway begins with the activation of initiator caspase-9. ${ }^{29)}$ Thus, the above results indicate that the activation of caspase- 9 may be triggered by caspase8-mediated Bid cleavage. Consequently, this study shows that these apoptotic pathways act in concert and lead to caspase-3 activation. In addition, these activations of caspases were in- 
hibited by catalase. Thus, our results demonstrate that $\mathrm{H}_{2} \mathrm{O}_{2}$ is a mediator of IAA/HRP-induced CD95 cell surface expression and that this activates an apoptotic pathway. We also found that a caspase-8 inhibitor, z-IETD-FMK restored IAA/HRP-induced apoptosis partially, thus confirming that caspase- 8 is involved in the IAA/HRP-mediated response. However, in agreement with the partial effect of antagonizing anti-CD95 antibody on cell viability (Fig. 4B), z-IETD-FMK also a showed limited effect. Therefore, further study is needed to clarify the mechanism underlying the apoptotic effects of IAA/HRP.

In summary, this study demonstrates that IAA/HRP produces $\mathrm{H}_{2} \mathrm{O}_{2}$, and that this activates a CD95-mediated apoptotic pathway in human melanoma cells.

Acknowledgements This work was supported by a Korea Research Foundation Grant funded by the Korean Government (MOEHRD) (Grant no. KRF-2004-E00166).

\section{REFERENCES}

1) Goldsmith M. H., Proc. Natl. Acad. Sci. U.S.A., 90, 11442-11445 (1993).

2) Wardman P., Curr. Pharm. Des., 8, 1363-1374 (2002).

3) Folkes L. K., Wardman P., Cancer Res., 63, 776 - 779 (2003).

4) Folkes L. K., Wardman P., Biochem. Pharmacol., 61, 129-136 (2001).

5) Kim D. S., Jeon S. E., Park K. C., Cell. Signal., 16, 81-88 (2004).

6) Kim D. S., Jeon S. E., Jeong Y. M., Kim S. Y., Kwon S. B., Park K. C., FEBS Lett., 580, 1439-1446 (2006).

7) Akiyama N., Shimma N., Takashiro Y., Hatori Y., Hirabayashi T., Horie S., Saito T., Murayama T., Cell. Signal., 17, 597-604 (2005).

8) Das M., Mukherjee S. B., Shaha C., J. Cell Sci., 114, 2461-2469 (2001).

9) Harper S. J., LoGrasso P., Cell. Signal., 13, 299-310 (2001).
10) Xia Z., Dickens M., Raingeaud J., Davis R. J., Greenberg M. E., Science, 270, 1326-1331 (1995).

11) Carvalho H., Evelson P., Sigaud S., Gonzalez-Flecha B., J. Cell. Biochem., 92, 502-513 (2004).

12) Itoh N., Yonehara S., Ishii A., Yonehara M., Mizushima S., Sameshima M., Hase A., Seto Y., Nagata S., Cell, 66, 233-243 (1991).

13) Suda T., Takahashi T., Golstein P., Nagata S., Cell, 75, 1169-1178 (1993).

14) Aragane Y., Kulms D., Metze D., Wilkes G., Poppelmann B., Luger T. A., Schwarz T., J. Cell. Biol., 140, 171-182 (1998).

15) Nicholson D. W., Ali A., Thornberry N. A., Vaillancourt J. P., Ding C. K., Gallant M., Gareau Y., Griffin P. R., Labelle M., Lazebnik Y. A., Munday N. A., Raju S. M., Smulson M. E., Yamin T. T., Yu V. L., Miller D. K., Nature (London), 376, 37-43 (1995).

16) Nagata S., Cell, 88, 355-365 (1997).

17) Luo X., Budihardjo I., Zou H., Slaughter C., Wang X., Cell, 94, 481490 (1998).

18) Denning T. L., Takaishi H., Crowe S. E., Boldogh I., Jevnikar A., Ernst P. B., Free Radic. Biol. Med., 33, 1641-1650 (2002).

19) Kirkman H. N., Rolfo M., Ferraris A. M., Gaetani G. F., J. Biol. Chem., 274, 13908-13914 (1999).

20) Dooley T. P., Gadwood R. C., Kilgore K., Thomasco L. M., Skin Pharmacol., 7, 188-200 (1994).

21) Kulms D., Dussmann H., Poppelmann B., Stander S., Schwarz A., Schwarz T., Cell Death Differ., 9, 598 - 608 (2002).

22) Kulms D., Zeise E., Poppelmann B., Schwarz T., Oncogene, 21, 5844-5851 (2002).

23) Zanke B. W., Boudreau K., Rubie E., Winnett E., Tibbles L. A., Zon L., Kyriakis J., Liu F. F., Woodgett J. R., Curr. Biol., 6, 606-613 (1996).

24) Peus D., Vasa R. A., Beyerle A., Meves A., Krautmacher C., Pittelkow M. R., J. Invest. Dermatol., 112, 751-756 (1999).

25) Park B. G., Yoo C. I., Kim H. T., Kwon C. H., Kim Y. K., Toxicology, 215, 115-125 (2005).

26) Facchinetti F., Furegato S., Terrazzino S., Leon A., J. Neurosci. Res., 69, 178-188 (2002).

27) Bennett M., Macdonald K., Chan S. W., Luzio J. P., Simari R., Weissberg P., Science, 282, 290-293 (1998).

28) Li H., Zhu H., Xu C. J., Yuan J., Cell, 94, 491-501 (1998).

29) Hengartner M. O., Nature (London), 407, 770—776 (2000). 